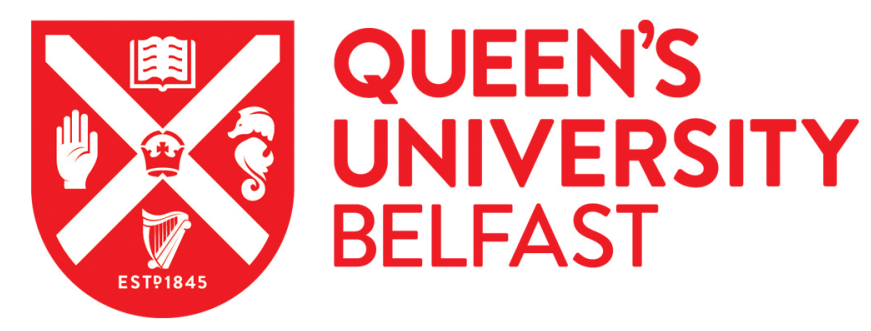

\title{
Between Law and Transnational Social Movement Organizations: Stabilizing Expectations of Global Public Goods
}

Hanna, M. (2017). Between Law and Transnational Social Movement Organizations: Stabilizing Expectations of Global Public Goods. Journal of Law and Society, 44(3), 345-373. https://doi.org/10.1111/jols.12034

Published in:

Journal of Law and Society

Document Version:

Peer reviewed version

Queen's University Belfast - Research Portal:

Link to publication record in Queen's University Belfast Research Portal

Publisher rights

(c) 2017 The Author. Journal of Law and Society. (@ 2017 Cardiff University Law School. This work is made available online in accordance with the publisher's policies. Please refer to any applicable terms of use of the publisher.

\section{General rights}

Copyright for the publications made accessible via the Queen's University Belfast Research Portal is retained by the author(s) and / or other copyright owners and it is a condition of accessing these publications that users recognise and abide by the legal requirements associated with these rights.

Take down policy

The Research Portal is Queen's institutional repository that provides access to Queen's research output. Every effort has been made to ensure that content in the Research Portal does not infringe any person's rights, or applicable UK laws. If you discover content in the Research Portal that you believe breaches copyright or violates any law, please contact openaccess@qub.ac.uk. 


\title{
Between Law and Transnational Social Movement Organisations: Stabilising Expectations of Global Public Goods
}

\author{
MARK HANNA*
}

This article draws on the theory and method of Niklas Luhmann to present transnational social movement organisations as a solution to the problem of increased expectations of global public goods which fail to find adequate accommodation in law. As a concrete example of the limits of law in this respect, the article examines the non liquet of the World Court on the question of the illegality of nuclear weapons. The trajectory of antinuclear norms is traced beyond the limits of law to the alternative structure of transnational social movement organisations, and the article presents such organisations as stabilising increased expectations of global public goods through their recursive decision-making and their capacity to continuously project those expectations at the legal and political systems. This generates observations on the concept of 'global governance', the structural relations between global civil society and international law, and the role of this form of organisation in the evolution of the global political system.

\footnotetext{
* School of Law, Queen's University Belfast, 27-30 University Square, Belfast BT7 1NN, United Kingdom I wish to thank Richard Nobles, David Schiff, Peer Zumbansen and Emilios Christodoulidis for their comments on an earlier draft.
} 


\section{INTRODUCTION}

Globalisation has led to increased expectations of what can aptly be described as 'global public goods'. The original economic idea of goods which are non-rival in their consumption and nonexcludable in their costs and benefits ${ }^{1}$ proves useful to conceptualising the temporal and spatial 'externalities' which emerged with globalisation. ${ }^{2}$ Of course, public goods often find their most cogent expression as negative externalities at the global level. Compared to positive formulations of 'common wellbeing' or even 'common humanity', problems like global warming, global financial crisis or nuclear war have a much more concrete 'universal reach', ${ }^{3}$ while the risk they pose proves much easier to generalise. ${ }^{4}$ Indeed the 'equalizing effect' of such problems can now galvanise common expectations of a significant class of world society, ${ }^{5}$ and in turn these expectations can increasingly find structure in a 'global public sphere' ${ }^{6}$ that is emerging with the advance of communication technology and the more general development of world society as a communicative network. This is not to say that such negative formulations of global public goods enjoy universal legitimacy — admittedly they often remain politically or scientifically contested. But they nonetheless remain relevant to law, ${ }^{7}$ for as long as the corresponding risks are perceived to be 'real', and that the conditions which underpin them are 'anthropogenic', ${ }^{8}$ they will generate global protest and a reference point for the development of law.

The modern legal system has nonetheless been exhausted by these developments. On the one hand, the accommodation of expectations of global public goods has been clearly limited

\footnotetext{
${ }^{1}$ P. Samuelson, 'The Pure Theory of Public Expenditure' (1954) 36 The Review of Economics and Statistics 387.

${ }^{2}$ W. Nordhaus, 'Paul Samuelson and Global Public Goods', in Samuelsonian Economics and the Twenty-First Century, eds. A. Gottesman, L. Ramrattan, and M. Szenberg (2006) 91.

${ }^{3}$ And, thus, a more urgent and concrete need for 'issue-specific policy and management', I. Kaul, 'Global Public Goods: Explaining their Underprovision' (2012) 15 Journal of International Economic Law 740.

${ }^{4}$ This is the reason they tend to be 'overprovided', D. Bodansky, 'What is in a Concept? Global Public Goods, International Law, and Legitimacy' (2012) 23 European Journal of International Law 658.

${ }^{5}$ U. Beck, Risk Society: Towards a New Modernity (1992) 36.

${ }^{6}$ M. Schiltz, G. Verschraegen and S. Magnolo, 'Open Access to Knowledge in World Society?' (2005) 11 Soziale Systeme 351.

${ }^{7}$ This needs to be stressed, as there is something of a dominating governance perspective in global legal studies which leads all too often to global public goods being hastily disregarded as irrelevant. See D. Augenstein, 'To Whom it May Concern: International Human Rights Law and Global Public Goods' (2016) 23 Indiana Journal of Global Legal Studies 246 (who, rightly concerned with the expansion of the state under the conditions of globalisation, nonetheless allows this perspective to obscure the relevance of 'interests and values of common concern'). See also, N. Walker, 'Human Rights and Global Public Goods: The Sound of One Hand Clapping?' (2016) Indiana Journal of Global Legal Studies 248, 253 (where the focus on 'political morality' and 'political authority' only leads to 'frustration with the phenomenon of one hand clapping').

${ }^{8}$ N. Oreskes, 'On the "Reality" and Reality of Anthropogenic Climate Change' (2013) 119 Climatic Change 560.
} 
by the foundational reference of public international law to sovereignty doctrine. ${ }^{9}$ Within this framework, expectations of global public goods are always liable to be frustrated by the 'privilege' of the sovereign nation-state. ${ }^{10}$ On the other hand, the problem cannot be solved purely in the private realm. ${ }^{11}$ Specialised private regimes operating beyond the nation-state will always struggle to accommodate the general nature of global public goods, just as they will always leave far too many hostages to fortune within the sovereign boundaries of nationstates. ${ }^{12}$ Despite globalisation, there is nothing to suggest state sovereignty is losing much of its operational value in legal and political decision making, and thus one can hardly expect programmatic and sustained attempts to address climate change or nuclear weapons, for example, without some kind of engagement with international institutions and, at least, the prospect of inducing the action of nation-states.

Typically, any approach departing from this perspective of increased expectations of 'global public goods' vis-a-vis the limits of the modern legal (and/or political) system, and seeking to explore solutions to this problem, will tend toward the 'global governance' paradigm. The distinction between 'governance' and 'government' has certainly allowed research to overcome the problematic of political organisation through sovereign nation-states and opened it to a much broader horizon of societal organisation. ${ }^{13}$ It offers in this sense a broad vista 'for describing growing complexity in the way the world is organized and authority exercised', ${ }^{14}$ and a way of constructing solutions to global problems of a public nature which 'cannot be addressed by states alone', and which must be addressed 'incrementally by diverse types of collectivities'. ${ }^{15}$

Whilst this article shares this focus of global governance studies to a degree, it aims to employ an alternative optic for examining the issue of global public goods and the limits of law. Though the category is vague enough to be inclusive, global governance studies share a core common focus on 'steering' and 'power' at the transnational level. Even in its broadest

\footnotetext{
${ }^{9}$ See N. Krisch, 'The Decay of Consent: International Law in an Age of Global Public Goods' (2014) 108 American Journal of International Law 1.

${ }^{10}$ D. Kennedy, 'The Mystery of Global Governance' (2008) 34 Ohio Northern University Law Review 849.

${ }^{11}$ This was the original point of the economic theory of public goods, op. cit. n.1.

${ }^{12}$ See G. Verscharaegen, 'Hybrid Constitutionalism, Fundamental Rights and the State' (2011) 40 Netherlands Journal of Legal Philosophy 224-225.

${ }^{13}$ As Weiss and Wilkinson point out, "to speak of "governance" and not "government" is to discuss the product and not the producer', T. Weiss and R. Wilkinson, 'Rethinking Global Governance? Complexity, Authority, Power, Change' (2014) 58 International Studies Quarterly 213.

14 id., p. 207. See also, C. Murphy, 'Global Governance: Poorly Done and Poorly Understood', (2000) 76 International Affairs 789.

${ }^{15}$ See J. Rosenau, 'Change, Complexity and Governance in a Globalizing Space', in Debating Governance, ed. Jon Pierre (2000) 167. See also, T. Risse, 2004. 'Global Governance and Communicative Action' (2004) 39 Government and Opposition 298.
} 
formulations, global governance is seen as occurring when transnational networks 'authoritatively steer constituents towards public goals', ${ }^{16}$ as a 'process whereby an organization or society steers itself', a process 'whereby values and behaviours at one level get converted into still other consequences at still more encompassing levels', and whereby 'commands flow in the form of goals framed, directives issued, and policies pursued' ${ }^{17}$

Governance, however, is not the only way to address this problem of global public goods and the limits of law. Beyond the problem of ensuring collectively binding decisions at the transnational level, there is also the different problem of stabilising expectations of global public goods which fail to find accommodation in law. To put it an anthropocentric way, where do people go with their expectations of global public goods when law clearly and categorically fails to give them any structure? This problem may be more abstract than global governance, but it is nonetheless just as discernible on examination. One can see the persistence of these expectations at various levels of world society, in the operation of peremptory norms, in transnational jurisprudence, in public interest litigation and letters to courts, in protest movements and the communications of a global civil society, in online social networks, in the newspapers, and public events staged by popular musicians and celebrities.

This article will use the functional method and systems theory of Niklas Luhmann as an alternative optic through which to explore the problem and its solutions. From this perspective, the political system - as one functional subsystem among others - appears less important. ${ }^{18}$ The function for which the political system is differentiated is characterised as the 'capacity to supply collectively binding decisions', ${ }^{19}$ and this presupposes the evolved institutionalisation of political power as a 'symbolically generalised medium of communication'. ${ }^{20}$ Such an arrangement has only come about at the national level through a long co-evolution of the political and legal systems which allowed each to externalise their foundational paradox in

\footnotetext{
${ }^{16}$ L. Andanova, M. Bestill and H. Bulkeley, 'Transnational Climate Governance' (2009) 9 Global Environmental Politics 56.

17 J. Rosenau, 'Governance in the Twenty-first Century' (1995) 1 Global Governance 14-16.

18 As King and Thornhill point out, 'the importance that Luhmann ascribes to the political system is strictly limited.' M. King and C. Thornhill, Niklas Luhmann's Theory of Politics and Law (2003) 70.

19 N. Luhmann, Political Theory in the Welfare State (1990) 74. See also, N. Luhmann, Die Politik der Gesellschaft (2000) 7.

${ }^{20}$ id. (1990), pp. 74, 157. See also N. Luhmann, A Sociological Theory of Law (1985) 85. 'Power' here is taken in a narrow sense, that is, from the trivial observation that, 'power is always a matter of a social relation in which action could have always been different on both sides of the relation.' One only submits to power if one can imagine and prefer other possibilities of action, while, on the other hand, one only exercises power where they perceive such 'other possibilities' and set out on a course of action to limit this. Luhmann labels this as 'double contingency', whereby things are neither 'necessary or impossible', and which therefore constitutes a problem for meaningful communication in society. Power is thereby 'recognizable and practicable only if the behaviour of the participants is ascribed to a symbolic code that describes the situations of power', Luhmann, op. cit. (1990), n. 19, pp. 155-57.
} 
such a way that violence exercised in the name of law could be referred to the will of the political sovereign, while at the same time the political system could refer to due process of law so that the nation-state's use of violence did not appear arbitrary. ${ }^{21}$ Obviously similar structural couplings have not yet evolved at the global level, and, as long as the global political system continues to be segmentarily differentiated into sovereign nation-states it is doubtful whether they ever will.

Luhmann's theory and method thus provide a different perspective on the problem from the global governance focus on 'steering' 22 and political power at the transnational level. ${ }^{23}$ What it offers instead is a perspective on the function of law in stabilising counterfactual expectations, as well as a useful corresponding method to search for functional equivalents. ${ }^{24}$ Although relatively unexplored, this proves useful for gaining insights into the problem of global public goods which cannot be addressed under current conditions and which rely instead on the evolution of world society. Using this theory and method, the article will construct the problem and its alternative solutions to provide information on the development of law and its functional equivalents in this reference. More specifically, the article will use this approach to present transnational social movement organisations (referred to simply as 'TSMOs' from here on) as functional equivalents to law in respect of expectations of global public goods.

In presenting this empirical possibility, the article will underline the important role TSMOs play in the global normative order and their contribution to meaningful communication about the global public goods which necessarily emerge with globalisation. But it will also generate information about the increasing role of TSMOs in the global political order. Although it aims to avoid the method and focus of global governance studies, highlighting the possible function of TSMOs in stabilising expectations of global public goods will hang a question over whether some of what is often captured and labelled as 'global governance' is not instead a different, apolitical function of stabilising expectations of global public goods which find no proper accommodation in traditional legal and political structures. Finally, whilst none of this amounts to the construction of social movement organisations taking part in global

\footnotetext{
${ }^{21}$ N. Luhmann, Law as a Social System (2004) 264.

22 The concept of 'steering' is particularly problematic from this perspective. See N. Luhmann, 'Limits of Steering' (1997) 14 Theory, Culture \& Society 41.

${ }^{23}$ Which is why accounts that have employed aspects of this approach to construct societal constitutionalism at the transnational level have so far been limited to a focus on 'constitutional fragments' and the pouvoir constituent within each differentiated normative order at this level, with all external relations characterised as cognitive and involving only learning pressures for the transfer of meaning from one different order to another. See G. Teubner, Constitutional Fragments: Societal Constitutionalism and Globalization (2012), or P. Kjaer, Constitutionalism in the Global Realm: A Sociological Approach (2014).

24 N. Luhmann, Social Systems (1995).
} 
governance and political power at the transnational level on an operational level, it will also raise a question as to whether the proliferation of TSMOs has some relevance for the global governance on the semantic level. That is, whether, in their increasing importance in the global normative order, TSMOs communicate a necessary 'opposition' to existing government - an alternative, that is, to the existing global political system, and thus a way out of the cul-de-sac of talking about political solutions to global problems in the international framework.

This is admittedly a bold development of Luhmann's theory. Luhmann can be said to have displayed a 'lack of sympathy' towards social movements, ${ }^{25}$ with some even going so far as to suggesting that he aimed to 'discredit' such movements. ${ }^{26}$ Moreover, it is true that Luhmann was generally sceptical about the extent to which social movements were capable of formal organisation, and, toward the end of his career, for example, was only prepared to admit that social movements 'secrete' organisation for 'residual purposes'. ${ }^{27}$ However, the organisation of social movements simply did not figure in Luhmann's research interests (i.e., the subject was not selected for research), and for that reason may represent something of a blind spot in his theory. Luhmann was aware, for example, that the inherent 'risk' which comes with technological development, and the increasing generalisation of values and norms that comes with advanced functional differentiation, were both placing an excessive burden on law, ${ }^{28}$ and even acknowledged the proliferation of social movements as a solution in this respect. ${ }^{29}$ As an avid reader who always kept abreast of developments in sociology, he should also have been aware of growing sociological research from the mid-1960s onwards which documented the increase in social movement organisation and focused on this development as important..$^{30}$

As will be demonstrated in the following analysis, it is a relatively short and straightforward step to extending this theory and method to construct the function of TSMOs

${ }^{25}$ I. Blühdorn, Post-Ecologist Politics: Social Theory and The Abdication Of The Ecologist Paradigm (2000) 126.

${ }^{26}$ S. Fuchs, 'The Self-Organization of Social Movements' (2006) 19 Systemic Practice and Action Research 1254.

${ }^{27}$ N. Luhmann, Theory of Society: Vol. 2 (2013) 156. See also, N. Luhmann, Risk: A Sociological Theory (1993) 128.

${ }^{28}$ Luhmann, op. cit., n. 21, pp. 468ff; Luhmann, op. cit. (1993), n. 27, p. 60.

${ }^{29}$ Luhmann, op. cit. (2013), n. 27, pp. 154-65; Luhmann, op. cit., n. 24, pp. 398-404; Luhmann, op. cit. (1993), n. 27 , pp. 125-45.

${ }^{30}$ See for example, M. Zald and R. Ash, 'Social Movement Organizations: Growth, Decay and Change' (1966) 44 Social Forces 327; J. McCarthy and M. Zald, The Trend of Social Movements in America: Professionalization and Resource Mobilization (1973); J. McCarthy and M. Zald, 'Resource Mobilization and Social Movements: A Partial Theory' (1977) 82 American Journal of Sociology 1212; Jenkins, J. 'Radical Transformation of Organizational Goals' (1977) 22 Administrative Science Quarterly 568-586; C. Tilly, From Mobilization to Revolution (1978); M. Zald and J. McCarthy, Social Movements in an Organizational Society (1987); J. Lofland, Social Movement Organizations (1996). 
in stabilising increased normative expectations of global public goods, and thereby providing a functional equivalent to law in this respect.

In order to arrive at this position, however, it is necessary to go through the process of applying the theory and method to the problem of global public goods which go under-realised in law. The first section of this article will therefore briefly introduce the functional method which will be used to gain this perspective. The second section will employ this to construct the problem of counterfactual expectations and show how law has traditionally provided the system through which the social force of those expectations can be channelled and 'cooledout'.

The third section will then turn to examining a concrete example of the limits of this problem-solution relationship in relation to global public goods. As law is not a system which easily admits limits, however, this need to be definite, and thus the article will identify and explore the non liquet of the World Court in the Nuclear Weapons opinion ${ }^{31}$ as a rare example of such clear limits to law in relation to a global public good. Expectations of the prohibition of the threat or use of nuclear weapons are a sound example of a negative formulation of a global public good. The potential catastrophic effects of nuclear weapons for humanity and the natural environment alike are clearly of "near universal' reach, ${ }^{32}$ and despite the fact that such a threat may appear too abstract for many, or even that some are satisfied with the tenuous, though necessary, arrangement of 'mutually assured destruction', there are enough people around the world who remain cognisant of the costs and benefits in this respect, and who perceive such weapons to be an unnecessary risk that only serves sectarian interests. While global governance of nuclear weapons is still vague and inadequate, ${ }^{33}$ the article will be able to focus on the more precise relationship between the problem of widespread anti-nuclear norms and their solutions at the transnational level.

Using this mark of the limits of law, the fourth section will trace those expectations to alternative social structures of antinuclear (that is, civil) organisations who carry the norm

\footnotetext{
${ }^{31}$ Legality of the Threat or Use of Nuclear Weapons, Advisory Opinion, ICJ Reports 1996 (just 'Nuclear Weapons Opinion' from here on).

${ }^{32}$ Even the 'tactical use' of such weapons would resonate at a near universal level. In 2003 the U.S. National Academy of Sciences, on request of Congress, conducted a study into military claims of the tactical use of nuclear weapons as 'robust nuclear earth-penetrating' (RNEP) weapons. The National Academy of Sciences concluded that such 'tactical use' could kill anywhere from 100,000 to 1 million people if detonated near a metropolitan area. The development of RNEP weapons was subsequently denied funding by Congress, see Effects of Nuclear Earth-Penetrator and Other Weapons (2005), Committee on the Effects of Nuclear EarthPenetrator and Other Weapons, Division on Engineering and Physical Sciences, National Research Council, Washington, DC: The National Academic Press.

${ }^{33}$ See R. Thakur, 'Nuclear Weapons: Global Governance Failing to Meet the Challenge' (2013), Asia Pacific Leadership Network for Nuclear Non-Proliferation and Disarmament, Policy Brief No. 3.
} 
along in their operations and promote it in their environment. This approach will finally present social movement organisations as functional equivalents to law in their ability to stabilise expectations of global public goods through recursive decision-making and through their ability to project the norms into their environment as proto-legal communications.

In the last section, the article will discuss these findings by commenting on the need for lawyers to devote more attention to social movement organisation and what it says about the fragmentation of the global normative order. At the same time, it will also examine the structural relation between transnational civil society organisations and the evolution of the political system in globalised society.

\section{THE FUNCTIONAL METHOD}

The functional method developed by Luhmann has received little attention in relation to the systems theory it produced. ${ }^{34}$ The centrality of this method to the present study, nonetheless, demands some definite statement of the approach at the outset. Although its roots can be traced to some extent to the 'functionalism' of Merton, Parsons and Durkheim, this method must be distinguished from much of that which preceded it in sociology. Rather than starting with a given social structure before construing how it contributes to society, Luhmann's approach involves a very definite methodology which starts with a problem and then looks for social structures which could serve as potential solutions. The goal here is not to establish causal relations between problems and solutions. The insight of the method, it is said, lies "athwart causalities: it resides in comparing them." 35 Does structure A, for example, provide a better solution to the problem than structure B? Established institutions can always be 'reproblematized'36 in this way and the problem used as a 'connecting thread' to further possibilities which can then be compared as 'functional equivalents'. ${ }^{37}$ This means that, initially at least, causalities can be assumed to be 'merely hypothetical', ${ }^{38}$ and the problemsolution relationships themselves can be acknowledged as 'constructions' of the observer'. ${ }^{39}$

\footnotetext{
${ }^{34}$ Luhmann himself explained it only on a few occasions, see N. Luhmann, 'Funktionale Methode und Systemtheorie' (1970) in Soziologische Aaufklärung, Vol. 1, 31-53; Luhmann, op. cit. n. 24, pp. 52-58.

35 id., p. 53.

${ }^{36}$ N. Luhmann, Art as a Social System (2000) 138.

${ }^{37}$ Luhmann, op. cit., n. 24, p. 53.

38 id.

${ }^{39}$ N. Luhmann, A Systems Theory of Religion (2013) 83.
} 
The method is thus deceptively simple, yet the complexity it reveals is formidable. By constructing a problem and then, rather than relying on taken-for-granted solutions, treating everything as contingent and searching out and comparing possible solutions on that basis, the observer is able to move past given social structures and thereby generate 'information'. ${ }^{40}$ The method thereby achieves a certain 'restlessness and an internal dynamic', driving analyses further and generating further questions. ${ }^{41}$ Only the insights gained through this method provide the 'scaffolding' upon which underlying causalities might be investigated on a more empirical level. ${ }^{42}$

This method is particularly suitable for analysing the problem of increasing expectations of global public goods which go under-accommodated in law. The general nature of such expectations, their formulation beyond established institutions and processes, means the problem can be easily obscured behind structures which have come to be taken for granted. This not only includes the structural conditions of sovereignty and dominating semantic value of the authority of law and politics within the institutional framework of nation-state and international organisations, but it also includes neo-liberal perspectives which assume an erosion of sovereign power with globalisation, and which thereby focus excessively on the development of law removed from state structures.

To apply this method, and thereby bring into view other possibilities, the next section will begin by re-problematizing the accommodation of growing expectations of global public goods in law. Functional analysis can be said to be 'as much about analysing the problem something is a solution to, as it is about analyzing how problems are solved. ${ }^{43}$ Thus, the problem must first be construed as a clear point of reference so that it may serve as a connection to further possibilities. Only once the problem has been theoretically constructed to a sufficient degree, can it be used to steer the functional method to search for 'tendencies that it regards as relevant and for which it can offer a meaningful interpretation. ${ }^{44}$

\footnotetext{
${ }^{40}$ Luhmann, op. cit., n. 24, p. 53.

${ }^{41}$ M. Knudsen, 'Surprised by Method: Functional Method and Systems Theory' (2010) 36 Historical Social Research 138.

${ }^{42}$ Luhmann, id., p. 54. Luhmann's epistemological constructivism meant he was sceptical about any claim to empirical reality, viewing such claims as 'constructions' of the observer, see N. Luhmann, Theory of Society, Vol. 1 (2012) 16. However, Luhmann's functional method still offers a valuable triangulation method which 'grasps' reality as a 'form of ordering vis-à-vis a reality that is also ordered', and thus provides a way for generating meaningful information and for sharpening theoretical insights, Luhmann, op. cit., n. 24, pp. 54-58. Moreover, it is not necessary to adopt the full epistemological implications of the theory of self-referential systems in order to use this functional method. For an example of effective use of this functional method for developing more empirical research, see C. Thornhill, A Sociology of Constitutions (2012).

${ }^{43}$ Knudsen, op. cit., n. 41, p. 133.

${ }^{44}$ C. Besio and A. Pronzini, 'Inside Organisations and Out: Methodological Tenets for Empirical Research Inspired by Systems Theory' (2011) 36 Historical Social Research 22.
} 


\section{NORMS AND THE FUNCTION OF LAW}

The problem of the limits of law in relation to increasing expectations of global public goods can only be glimpsed if one moves beyond the traditional distinction between facts and norms and the limitation of 'norms' to formally positivized rules. ${ }^{45}$ The concept of 'norms' must include the more basic social elements of counterfactual expectations, that is, expectations which signify a determination not to learn from disappointment. ${ }^{46}$ At the same time, the distinction between cognitive and normative expectations proves more useful-and much more 'sociological' in terms of examining the elementary social conditions of law-than the more often used distinction between primary and secondary norms. ${ }^{47}$ The problem of expectations which, rather than learning through disappointment, are 'adhered to, even when frustrated' ${ }^{48}$ is a problem for meaningful communication which leads to the emergence of 'second level' social structures to channel and augment the expectation and absorb any uncertainty surrounding it. ${ }^{49}$ For this reason, norms are seen to be endowed with a social force that stimulates the evolution of structures in which these expectations can be stabilised. In other words, they are a communicative dissent which enables the 'take-off of social evolution'. 50

Law is the classic example of the social system which provides for this stabilisation of norms. ${ }^{51}$ Traditionally, the legal system has provided social support for contra-factual expectations 'in a way that no other system does'.52 As formulated by Luhmann, law's specialisation in this respect lies in its ability to simultaneously 'generalize' normative

${ }^{45}$ See, for example, G-P. Calliess, 'Reflexive Transnational Law: The Privatisation of Civil Law and the Civilisation of Private Law', 23 Zeitschrift für Rechtssoziologie (2002) 195f.

${ }^{46}$ N. Luhmann, 'Are There Still Indispensable Norms in Our Society?' (2008) 14 Soziale Systeme 33. See also Luhmann, op. cit. (1985), n. 20, p. 32; Luhmann, op. cit., n. 21, p. 149.

${ }^{47}$ H.L.A. Hart, The Concept of Law (1996). This also applies to approaches which rely on the distinction for constructing societal constitutionalism and which pay less attention to the problem of stabilising highly generalised normative expectations, see for example, G. Teubner, 'A Constitutional Moment? The Logics of 'Hitting the Bottom', in The Financial Crisis in a Constitutional Perspective, eds. P. Kjaer and G. Teubner (2011) 27-28.

${ }^{48}$ Luhmann, op. cit. (2008), n. 46, p. 33.

${ }^{49}$ E. Christodoulidis, Law and Reflexive Politics (1998) 120. See also Luhmann, op. cit., n. 24, p. 324.

${ }^{50}$ H. Brunkhorst, Critical Theory of Legal Revolutions: Evolutionary Perspectives (2014) 15. See also Habermas, who, although he rejected the 'time binding' element of the norm, conceives of normative expectations as providing the "'must" of a weak transcendental necessity' which forms the basis of complex negotiation between facts and validity, J. Habermas, Between facts and Norms (1996) 4, 17.

${ }^{51}$ Of course, law's autonomy will depend upon its own selection of norms for legal institutionalisation, yet law's function will refer its operations to well organised and communicated behavioural expectations which resist disappointment.

${ }^{52}$ Christodoulidis, op. cit., n. 49, p. 122. 
expectations in three separate dimensions: the temporal, social and factual dimensions. ${ }^{53}$ Briefly stated, generalising the norm along the temporal dimension involves the institutionalisation of the time-binding form of normative expectations. Just as the normative expectation is projected against a disappointing future, law - as a system that operates through provisions which are binding in the future-is able to provide a medium which will carry this normativity through time and project it at a discrepant reality in the future. Generalisation of the norm in the social dimension, on the other hand, occurs when anonymised third parties represented by the institution also normatively co-expect it. This institutionalisation allows for expectations to be uploaded to a more systemic context and to be thereby generalised beyond the immediate interactional setting. Finally, the norm is generalised in the factual dimension of law when it is linked with some more abstract principle of meaning beyond the immediate interactional context. Rather than seeking meaningful identification with every individual expectation, law provides 'more abstract types which can be held constant and then function as generative rules for individual expectations. ${ }^{54}$ A new dishwasher machine that due to faulty internal wiring gives its owner a violent electric shock, a defective car tyre that blows out for no apparent reason causing the driver to crash into another vehicle, or the storage of hazardous waste that accidently leaks into local wells and forces the municipality to spend money on a filtration system, are all very different fact patterns that may nonetheless garner expectations which attach to the same abstract principle of strict liability in tort. In this way, legal meaning can be said to provide a 'context of expectations', and thereby endow the norm with further meaning and stabilise it against contradictory facts. ${ }^{55}$

Luhmann presents the function of law as the 'congruent generalisation' of behavioural expectations in all three of these dimensions at once. ${ }^{56}$ The improbability of this achievement takes on a central importance for the systems theoretical concept of the function of law, yet the scheme will be used here as a measuring device to compare functional equivalents to law in stabilising normative expectations of global public goods. Expectations of global public goods which go under-accommodated in law must also be recognised as normative in so far as they can resist disappointing experience. Expectations of global public goods will not simply learn if they fail to find accommodation in law. Moreover, these expectations are now so organised and purposely communicated that they cannot be limited to the vague concern of the morality

\footnotetext{
${ }^{53}$ Luhmann, op. cit. (1985), n. 20, p. 77.

${ }^{54}$ id., p. 64.

55 id.

${ }^{56}$ id., p. 77.
} 
system. Something more concrete is needed to foster and carry these counterfactual expectations so that they can be projected against any discrepant reality in the future. Thus it is useful to identify a concrete example of the limits of law in relation to such normative expectations. This will not only refine understanding of the problem, but it will reveal the 'connecting threads' to a solution.

\section{A CONCRETE EXAMPLE OF THE LIMITS OF LAW}

Drawing attention to the limits of law is by no means easy. While lawyers may be consumed with an argumentative practice predicated upon distinguishing between 'what is legal, and what is not', the limits of law remain notoriously elusive.$^{57}$ Law's expansive tendencies mean that it has evolved techniques for clouding the very issue of its own boundaries, and this faculty has proved especially useful for maintaining law's functional relevance in globalised society. ${ }^{58}$ There is, however, one concrete example of the limits of law in reference to expectations of global public goods: the World Court's 1996 advisory opinion on the legality of the threat or use of nuclear weapons. ${ }^{59}$

Expectations of the prohibition of the threat or use of nuclear weapons found increasing formulation in world society after their use at the end of the Second World War, although expression of antinuclear norms became more pronounced from the 1960s onwards. By the early 1990s, such expectations had gathered enough momentum to prompt the World Health Organisation (WHO) ${ }^{60}$ and the United Nations General Assembly (UNGA) to request an advisory opinion of the court in The Hague on the question as to whether the threat or use of nuclear weapons is permitted under international law. ${ }^{61}$ On admitting the request, the Court acknowledged its objective was 'to determine the legality or illegality of the threat. ${ }^{62}$ No sooner had the Court embarked upon the task, however, when it was confronted with the

\footnotetext{
${ }^{57}$ J. Raz, 'Legal Principles and the Limits of Law' (1972) 81 The Yale Law Journal 823.

${ }^{58}$ See, for example, M. Hanna, 'The Procedural/Substantive Distinction: Judicial Solutions to the Problem of Jus Cogens in a World of Sovereign States' (2017) 18 The German Law Journal (forthcoming).

59 op. cit., n. 31 .

${ }^{60}$ WHA46.40, adopted by the World Health Assembly on 14 May 1993. The ICJ, however, held that the matter did not fall within the competence of the WHO. See, Request for an Advisory Opinion, Legality of the Use by a State of Nuclear Weapons in Armed Conflict, ICJ Reports 1993. The Court, however, admitted the UNGA's request, see Request for Advisory Opinion transmitted to the Court under the United Nations General Assembly resolution 49/75 K of 15 December 1994.

${ }^{61}$ A/RES/49/75k, Request for an Advisory Opinion, 15 December 1994.

${ }^{62}$ Nuclear Weapons Opinion, para. 20.
} 
constraints of 'the policy of deterrence' that had been adhered to for many years by an 'appreciable section of the international community', ${ }^{63}$ and the 'fundamental right' of national self-defence contained in Article 51 of the United Nations Charter. ${ }^{64}$ Stumped by the tension between these structural constraints and the importance of the nuclear weapons question, the Court was forced to admit that it was having difficulty reaching a 'definitive conclusion as to the legality or illegality of the use of nuclear weapons'. ${ }^{65}$ In the end, by seven votes to seven with the President's casting vote, the Court conceded that it could not 'conclude definitively whether the threat or use of nuclear weapons would be lawful or unlawful in an extreme circumstance of self-defence'. ${ }^{66}$

This is generally accepted to be a rare example of non liquet. ${ }^{67}$ The principle of non liquet (which literally means 'its not clear') has undergone a 'long evolutionary process' to emerge in modern legal systems as a prohibition of the denial of justice and a compulsion on courts to decide every case that is admitted before them. ${ }^{68}$ Today that principle is codified in the constitutional provisions of many civil law jurisdictions, ${ }^{69}$ and is widely reflected in common law systems which have accommodated "the institution of "judge-made" law."70 Traditionally, international law was able to reflect this general evolution of law and present itself as a complete legal order by relying on the 'residual negative principle' that found its classical statement in the judgment of the Permanent Court in the 1927 Lotus case: 'whatever is not expressly prohibited by international law is permitted'. ${ }^{71}$ This led Kelsen, for example, to consider that non liquet in international law was 'logically not possible'. ${ }^{2}$

While this line of thinking may have staved off questions about the completeness of the international legal system for some years, the advent of globalised society and the consequential explosion of global norms quickly called the principle into question. In his

\footnotetext{
63 id., para. 96.

64 id.

65 id., para. 97.

${ }^{66}$ id., para. $105(2)(\mathrm{e})$.

${ }^{67}$ Nuclear Weapons Opinion, Declaration of President Bedjaoui, para. 14; Declaration of Judge Vereschetin, 279; Dissenting Opinion of Vice President Schwebel, 322; Dissenting Opinion of Judge Higgins, para. 30; D. Bodansky, 'Non Liquet and the Incompleteness of International Law', in International Law, The Court of Justice and Nuclear Weapons, eds. L. Boisson de Charzournes and P. Sands (1999) 153; M. Koskenniemi, The Silence of Law/The Voice of Justice, id., p. 489.

68 A. M. Rabello, 'Non Liquet: From Modern Law to Roman Law' (2004) 10 Annual Survey of International \& Comparative Law 2.

${ }^{69}$ See, for example, Article 4 of the Code Civil des Français, Article 4 of the Belgian Civil Code; Article 1(20) of the Swiss Civil Code; Article 1(7) of the Spanish Civil Code; Foundations of Law, 5740-1980.

${ }^{70}$ M. Reisman, 'International Non-Liquet: Recrudescence and Transformation' (1969) 3 International Lawyer 770; see also Rebello, op. cit., n. 68, p. 5.

${ }^{71}$ S.S. Lotus, (France v Turkey), Judgment, PCIJ Series A no 10, ICGJ 248 (PCIJ 1927), Permanent Court of International Justice, 18-19.

${ }^{72}$ H. Kelsen, Principles of International Law (1966) 438-40.
} 
declaration in the Nuclear Weapons opinion, the President of the Court remarked on how the world had changed since the Lotus case-how 'globalization' and 'progress in the technological sphere, which now makes possible the total and virtually instantaneous eradication of the human race' had necessitated a move away from an international law of 'cooperation' to one of 'co-existence'. ${ }^{73}$ The World Court, he argued, was in a much more difficult position than the Permanent Court that decided the Lotus case in 1927, and could not, therefore, follow the residual negative principle, but instead had to assert a new counter principle that "what is not expressly prohibited by international law is not therefore authorized. ${ }^{74}$

Whatever reasons lay behind it, the non liquet in the Nuclear Weapons opinion represents a clear limit to law in relation to cogently formulated expectations of a global public good. In order to promote the recursivity of system-specific communications, and generally stimulate communication in a way to stop itself from 'running aground' ${ }^{75}$ law must apply its own internally constructed binary code (e.g., 'legal/illegal') to proceedings. This is how the system secures its autopoiesis under limited conditions. ${ }^{76}$ But just as importantly, this also secures the legal system's function. When the social system uses a problem-reference as a 'guiding difference' for the construction of its own binary code, and when it achieves its autopoiesis on this basis, the system acquires 'universal relevance' for the problem. ${ }^{77}$ In other words, if the legal system runs aground in reference to cogently formulated normative expectations, it will lose its functional relevance in this respect, and the problem will look for solutions in functional equivalents which can so sustain themselves in this reference.

In her dissenting opinion in the Nuclear Weapons case, Judge Higgins reminded the Court that there are 'useful devices' which 'preclude the Court from pleading non liquet in any given case'. ${ }^{78}$ Yet, it seems the difficulties in the case of nuclear weapons were such that the Court could not employ these devices. The Court failed to apply its own code to the question, and the non liquet involved the admission of a 'rejection value', that is a 'third value' from beyond the international legal system which negated the binary code of legal/illegal as the basis

\footnotetext{
${ }^{73}$ Nuclear Weapons Opinion, Declaration of President Bedjaoui, 270-271.

74 id., para. 15.

${ }^{75}$ Luhmann, op. cit. (2013), n. 27, p. 91.

${ }^{76}$ N. Luhmann, Ecological Communication (1989) 38-39.

77 On the relationship between coding and function, see id.; Luhmann, op. cit., n. 39, p. 88.

78 Nuclear Weapons Opinion, Dissenting Opinion of Judge Higgins, para. 38. Lauterpacht's view that the 'prohibition of non liquet constitutes one of the most undisputedly established rules of positive international law' evidently haunted the members of the bench, see H. Lauterpacht, 'Some Observations on the Prohibition of Non Liquet and the Completeness of the Legal Order' (1958) Symbolae Verzijl 200.
} 
of choice. ${ }^{79}$ This not only invited systemic 'disintegration' and threatened to expose foundational paradoxes of the legal system, ${ }^{80}$ but, more importantly for present purposes, it negated the function of law in reference to normative expectations of the prohibition of nuclear weapons. As international law could not reproduce and expand itself on this basis, nor could it function to stabilise such normative expectations. Sitting at the centre of the only legal system which can address expectations that sovereign states will be constrained in the threat or use of such weapons, the Court's communicated failure to apply its own code to the question involved a loss of universal functional relevance to antinuclear norms for law in general.

Despite this loss of functional relevance to the anti-nuclear norm, however, the Court's opinion in no way revoked or muted the recognition that the norm had received in the process leading up to the conclusion of the opinion. The Court did not state that nuclear weapons were 'legal' and that expectations of the prohibition of nuclear weapons should, therefore, be modified - that they should learn to live with the disappointment. The case is unique because it explicitly denied the residual negative principle of the Lotus judgment. In that sense, the Court's non-decision left room for, even promoted, the formulation and recognition of antinuclear norms at a more primary social level, and may even have further primed its counterfactuality in this respect. ${ }^{81}$

The Nuclear Weapons Opinion is, therefore, a rare example of the clear limits of law in relation to expectations of global public goods, as well as a flashpoint recording the persisting normativity of those expectations. This is what invites a search for functional equivalents. From a systems theoretical perspective, one can suppose that, despite law's failure, society has evolved, and even that 'the problem will have already been solved' ${ }^{82}$

\section{THE SOLUTION OF TRANSNATIONAL SOCIAL MOVEMENT ORGANISATIONS}

One does not need to search extensively along the path of antinuclear expectations at the site of the limits of law to reveal alternative structures that could provide solutions to the problem.

\footnotetext{
${ }^{79}$ A. Philippopoulos-Mihalopoulos, 'Boundaries of Exclusions Past: The Memory of Waste', in Imaginary Boundaries of Justice: Social and Legal Justice Across Disciplines, ed. R. Lippens (2004) 84. See also, Luhmann, op. cit., n. 21, p. 281. ${ }^{80} \mathrm{id}$.

${ }^{81}$ Despite its non-decision, the Court also, for example, noted the 'unique' characteristics of nuclear weapons in holding a destructive power which 'cannot be contained within space or time', their 'potential to destroy all civilization and the entire ecosystem of the planet' (Nuclear Weapons Opinion, para. 35), and even that such weapons 'seems scarcely reconcilable' with the law of armed conflict (para. 95).

${ }^{82}$ Luhmann, op. cit., n. 39 , p. 82.
} 
These structures were clearly noted by several of the judges in their separate opinions in the Nuclear Weapons case as the 'powerful pressure groups' and 'NGOs' which provided the impetus for the request for an advisory opinion, ${ }^{83}$ and which were noted to 'come from all countries, cover all walks of life, and straddle the globe'. ${ }^{84}$ The Nuclear Weapons Opinion has ultimately become a 'famous example' of the influence of transnational civil society organisations on judicial proceedings in a legal system which has traditionally afforded little recognition to any subjects other than nation-states and international organisations. ${ }^{85}$

The projection of the antinuclear norm before the World Court was a result of a 'World Court Project' launched by three civil society organisations in 1992: International Physicians for the Prevention of Nuclear Weapons (IPPNW), International Association of Lawyers Against Nuclear Weapons (IALANA), and the International Peace Bureau (IPB) ${ }^{86}$ The IPPNW had originally mounted a 'coordinated intensive campaign' in every country in which it had members, visiting national health ministers and making further 'soundings' within the WHO bureaucracy as to the viability of the resolution requesting an advisory opinion from the Court. ${ }^{87}$ When the WHO met for its annual general assembly in Geneva in 1993, the IPPNW sent its own delegation to lobby health ministers for a resolution requesting an advisory opinion on a question that was drafted by IALANA lawyers. ${ }^{88}$ At the same time, the organisations were lobbying the Non-Aligned Movement within the UNGA as an alternative, more robust, route to securing an advisory opinion of the World Court on the issue. Despite the fact that civil society groups have no right of representation before the Court in advisory opinions, once the UNGA resolution had been secured, the organisations became heavily involved in preparing submissions for the case, with IALANA offering 'on the spot' legal advice to any supportive government deputations. ${ }^{89}$

Since the 1996 advisory opinion, the IPPNW, IALANA and other organisations have continued to pursue the goal of a world free of nuclear weapons. As part of its 'Back to Court'

\footnotetext{
${ }^{83}$ Nuclear Weapons Opinion, Dissenting Opinion of Judge Oda, 335-336.

${ }^{84}$ Nuclear Weapons Opinion, Dissenting Opinion of Judge Weeramantry, 533.

85 A-K. Lindblom, Non-Governmental Organisations in International Law (2005) 219; see also P. Sands, 'International Law, the Practitioner and Non-State Actors', in The International Lawyer as Practitioner, ed. C. Wickremasinghe (2000) 103.

${ }^{86}$ Written Statement of the Government of the United Kingdom, International Court of Justice, Legality of the Threat or Use of Nuclear Weapons, June 1995, para. 2.3; D. Krieger \& V. Nanda, Nuclear Weapons and the World Court (1998) 69; Lindblom, id., p. 219; L. Wittner, Confronting the Bomb: A Short History of the Nuclear Disarmament Movement (2009) 207.

${ }^{87}$ K. Dewes and R. Green, 'The World Court Project', in War or Health: A Reader, eds. I. Taipale et al (2002) 501.

88 id.

89 id., p. 505.
} 
project, ${ }^{90}$ IALANA, for example, has worked with another civil society organisation, the Nuclear Age Peace Foundation, to shepherd claims brought by the Royal Marshall Islands (RMI) - a small island state which has suffered health and environmental problems due to a history of explosive testing of nuclear weapons in the South Pacific-against prominent nuclear weapons states. This has included an application to the World Court against nine nuclear weapons states for their failure to comply with their obligations under the 1995 NonProliferation Treaty (NPT) - although this time the Court was not going to make the same mistake it did in 1996, and thus used procedure (not substance!) to declare that there was no dispute that would serve as the basis of the Court's jurisdiction. ${ }^{91}$ The 'Back to Court' project also included a similar complaint filed against the United States government in a U.S. Federal District Court in 2014, which was dismissed because, inter alia, it raised a 'fundamentally nonjusticiable political question'. ${ }^{92}$ In both cases, IALANA has been actively involved in the RMI's applications. The organisation's vice president was the chair of the RMI's lawyer's committee, and IALANA lawyers were reported to be working a lot on the case behind the scenes. ${ }^{93}$

The IPPNW, on the other hand, has pursued a nuclear weapons ban treaty to be ratified by the majority of non-nuclear weapons states in the hope of eventually pressuring nuclear weapons states into compliance. Frustrated with the lack of progress at NPT Review Conferences and inspired by the notorious well-organised and cohesive civil society campaign which led to the adoption of the Ottawa Treaty banning landmines, ${ }^{94}$ the organisation decided in 2007 to establish the International Campaign to Abolish Nuclear Weapons (ICAN), as the 'the next stage of doctors, mayors and citizens joining with governments to work for a Nuclear Weapons Convention'. 95 A clear example of what Ahrne and Brunsson call a 'metaorganization', ${ }^{96}$ ICAN has been heavily involved with organising the 2014 Vienna Conference

\footnotetext{
${ }^{90}$ See 'Return to the International Court of Justice: A Strategy to Break the Stalemate', August 2007, available at LNCP website, <http://www.lcnp.org/wcourt/memoreturnICJhead.pdf>.

91 Obligations concerning Negotiations relating to Cessation of the Nuclear Arms Race and to Nuclear Disarmament, Marshall Islands v United Kingdom, ICJ Reports 2016. See the same decisions in respect of the same claims made against The United States, Russia, China, France, Israel, India, Pakistan, and the Democratic People's Republic of Korea. All are available at the ICJ website.

92 Order Granting Motion to Dismiss, The Republic of the Marshall Islands v The United States of America, 3 February 2015. Available at Nuclear Zero website, < http://www.nuclearzero.org/in-the-courts >.

93 'Civil Society Presentations, 2014 NPT PrepCom', 29 April 2014, Special IALANA Newsletter, available at LNCP website, < http://www.lcnp.org/RMI/IALANA-Newsletter_14_7.pdf>.

${ }^{94}$ L. Wittner, 'Where is the Nuclear Abolition Movement Today?', in Disarmament Forum: Civil Society and Nuclear Disarmament, The United Nations Institute for Disarmament Research (2010) 5.

95 'IPPNW Launches International Campaign to Abolish Nuclear Weapons', available at IPPNW website, 'Official IPPNW Statements', < http://www.ippnw.org/statements.html >.

${ }^{96} \mathrm{G}$. Ahrne and N. Brunsson, Meta-Organizations (2008). ICAN has specific criteria for membership for partner organisations, namely pledging to promote the campaign's objective of a treaty banning nuclear weapons,
} 
on the Humanitarian Impact of Nuclear Weapons, where the Austrian government made a 'pledge' to identify and pursue effective measures to 'fill the legal gap' for the prohibition and elimination of nuclear weapons. ${ }^{97}$ Although the Vienna Conference did not result in a 'norm cascade ${ }^{98}$ in the way that the Ottawa Conference did for landmines, it was nonetheless notable for ICAN's ability to establish structural relations with national governments, international organisations and key transnational civil society organisations such as Amnesty International and The International Committee of the Red Cross. ${ }^{99}$

These are just a few examples of the actions these organisations have taken in recent years for the promotion of the anti-nuclear norm in world society. But what is important to note in these examples is the way in which these entities have pursued the goals of the anti-nuclear movement through formal organisation. The IPPNW, for example, is a formal organisation with a constitution which clearly establishes its goals in advancing 'research, education, and advocacy relevant to the prevention of nuclear war'; 100 its membership is open to those national or regional medical organisations or individuals who are judged to be 'working for' the established goals of the organisation in the prevention of nuclear war; ${ }^{101}$ and this is overseen by a hierarchical structure, with an International Council which meets at least once every other year, and a Board of Directors which is appointed by the Council to implement IPPNW's policies. ${ }^{102}$ IALANA is also a formal organisation with established goals for the complete elimination of nuclear arms and the prevention of nuclear war;' ${ }^{103}$ membership is based on agreement and conduct in accordance with IALANA's goals; ${ }^{104}$ and the organisation has a hierarchy represented by a General Assembly as its 'supreme body', ${ }^{105}$ and a Board of Directors

\footnotetext{
identifying publicly with the campaign, and operating non-violently. ICAN has an internal hierarchy, with its apex represented in the International Steering Group (ISG) which oversees the strategic planning, campaign building, fundraising, policy formulation, information sharing, and coordination of international events. The ISG meets regularly to take decisions on its decision-premise of securing a treaty banning nuclear weapons, see 'ICAN International Structure', available at ICAN website, 'Structure and People', <http://www.icanw.org/campaign/structure-and-people/>.

97 'The Vienna Convention on the Humanitarian Impact of Nuclear Weapons, 8-9 December 2014', available at BMEIA, Außenministerium Österreich website, 'HINW14Vienna -Statements', <http://www.bmeia.gv.at/>. See also, 'A Pledge to Fill the Legal Gap: Vienna Conference 2014', available at ICAN website, $<$ http://www.icanw.org/resources/publications/>.

${ }^{98}$ M. Finnemore \& K. Sikkink, 'International Norm Dynamics and Political Change' (1998) 52 International Organisation (1998) 887.

${ }^{99}$ See, 'A Pledge to Fill the Legal Gap', op. cit., n. 97.

${ }^{100}$ Constitution of the International Physicians for the Prevention of Nuclear War, as amended 26 August 2014 , Section 2.1.

101 id., Section 3.1.

102 id., Sections 4.0, 4.1, 4.2.

${ }^{103}$ IALANA Statute, Article II (1).

104 id., Article III (1).

105 id., Article V (1).
} 
who 'support and supervise' an Executive Committee which is charged with implementing the policy of the organisation. ${ }^{106}$

Traditionally, under the dominance of Weberian notions of organisation, it was thought that the reliance of protest movements upon organisation would only lead to a collapse into bureaucracy and conformity with the status quo ante. ${ }^{107}$ Yet, since the $1960 \mathrm{~s}$, social scientists have drawn attention to the way in which protest movements have increasingly relied upon formal organisation for improved administration, leadership, collection of resources and to encourage participation in the social movement. ${ }^{108}$ Indeed, the emergence of organisations like the IPPNW and the IALANA in the 1980s can be seen a part of a well-noted proliferation of TSMOs in world society since the 1970s. ${ }^{109}$ The singular commitment of these organisations to the normative goals of specific protest movements endows them with a special autonomy. Unconcerned with profit or other parochial interests, they function to promote 'collective benefits, public good, the common weal, or the welfare of diffuse categories' ${ }^{110}$ Because they do not have to answer to shareholders or an electorate and are absolved from responsibility for broader political objectives, they can focus on the promotion of specific norms. ${ }^{111}$

\section{The function of social movement organisations in stabilising norms}

A delicate balance has thus been achieved between formal organisation and the promotion of the normative goals of spontaneous protest movements, and the singularity of this achievement marks social movement organisation as a potential solution to the problem of increasing expectations of global public goods which go under-accommodated in law. If one takes the meaning dimensions which Luhmann used to construct the function of law-meaning dimensions which are used to 'emphasize the universality of the claim to validity'112 - then the formal organisation of social movements can be seen to carry out a similar function.

This is most evident in relation to the social dimension. As stated, norms will be generalised in this dimension when they are co-expected by anonymous third parties

\footnotetext{
106 id., Articles VII (2) and VIII (2).

${ }^{107}$ M. Weber, Economy and Society (1968) 297; See also R. Michels, Political Parties (1949). As stated, Luhmann also carried on this view to an extent, Luhmann, op. cit., n. 27.

108 Zald and Ash, op. cit., n. 30.

${ }^{109}$ J. Smith, Social Movements for Global Democracy (2008) 121-125; J. Smith, 'Globalization and Transnational Social Movement Organizations', in Social Movements and Organisation Theory, eds. M. Zald et al. (2005), 226-32.

${ }^{110}$ J. Boli \& F. Lechner, World Culture Origins and Consequences (2005) 123.

111 id., p. 124.

${ }^{112}$ Luhmann, op. cit., 24, p. 76.
} 
represented by the institution. Not only do these organisations represent normative expectations of global public goods, but the norms often provide the basis of the formal structure of many of those organisations. The 'goals' of Greenpeace, for example, may include 'stopping forestation for palm oil', 'stopping overfishing in the high seas', 'ending the use of hazardous chemical globally', and so on, ${ }^{113}$ while the criteria for membership is an agreement to 'pursue objectives compatible' with those goals, ${ }^{114}$ and Greenpeace has a Council which makes decisions to that end, and an International Board which ratifies and carries out those decisions. ${ }^{115}$ As such, social movement organisations can be said to stand for certain norms. They are collective action on the specific issue of the norm, and as removed institutional structures they provide for the generalisation of those expectations beyond the immediate interaction context in which such norms might arise. ${ }^{116}$ The normative expectations of people living in the most remote parts of the world will be echoed by the expectations of anonymised third parties represented by the organisation. And this social generalisation is only more effective if the organisation is based as 'far away' as Amsterdam, Geneva or any other city in the 'Global North'. ${ }^{117}$ They institutionalise the norm on the world stage.

In the factual dimension, it is clear that, as far as the normative basis of the decisions and goals of social movement organisations are communicated, they provide a broader context to which expectations arising in various social situations throughout the globe can be linked, and are thereby imbued with a deeper meaning. Thus, for example, normative expectations of the prohibition of the threat or use of nuclear weapons may arise in different interactional settings, from the inhabitants of a small Pacific island state with expectations in relation to problems they face today as a result of explosive testing in their region, to the citizens of a global city who see nuclear weapons as an unjustifiable global risk, to officials of an independent nation-state who oppose nuclear weapons as a threat to their own national security. Yet, all of those expectations can attach to the more abstract decision premise of the organisation devoted to the elimination of nuclear weapons, and can gain meaning through the association. Admittedly, there is not the same scope for the scale of the cultural store of ideas

\footnotetext{
113 Greenpeace 2013 Annual Report.

${ }^{114}$ Stichting Greenpeace Council Rules of Procedure, as approved at the AGM 2014, Section. 2.3.

115 id. Sections 4 and 5.

116 This faculty is well documented by constructivist international relations scholars who present transnational nongovernmental organisations as key 'promoters of norms' in world society, see for example, K. Sikkink, 'Restructuring World Politics: The Limits and Asymmetries of Soft Power', in Restructuring World Politics Transnational Social Movements, Networks, and Norms, eds. S. Khagram, J. Riker \& K. Sikkink (2002) 301.

117 A counter-perspective from the common critique of the location of social movement organisations in the 'Global North', see for example K. Sikkink and J. Smith, Infrastructures for Change: Transnational Organisations, id., pp. 24, 35 .
} 
that we expect from law. But this only highlights a key insight about this development: the proliferation of social movement organisations suggests instead that society is evolving towards a much more fragmented institutionalisation of norms.

Finally, this leads to the temporal dimension, and perhaps the most important, as this appears to be the cornerstone of the specialisation of social movement organisation. As stated, Luhmann did not explore the function of social movement organisation, yet the blueprint for the function in the temporal dimension can be developed by mining the insights of his organisational theory. According to this, organisations differentiate themselves on the basis of their decisions - they 'produce decisions from decisions, and in this sense are operationally closed systems.' 118 This is built on the idea that every decision serves as a 'premise' for later decisions in the organisation. ${ }^{119}$ The decision premise is not re-opened, to be decided again, as this would only paralyse the organisation. Rather it is taken as decided, and thereby provides a structural precondition of further decisions. The decided decision premise thereby becomes the organisation's formal structure, ${ }^{120}$ generating 'possibilities for decision-making that would not otherwise exist'. ${ }^{121}$ For example, an organisation may decide that the United Nations Universal Declaration of Human Rights should be a 'reality for the world's people'. ${ }^{22}$ Thereafter, all decisions on membership, on funding, on future projects, and so on, will grow out of this original decision premise. It is for this reason that organisations are described as 'decision machines', ${ }^{123}$ or 'systems made up of decisions'. ${ }^{124}$ The organisations cannot make decisions outside of itself, ${ }^{125}$ and, at the same time, every formal decision, from the founding of the organisation to the occupation of membership roles by persons, must be 'treated recursively in the organisation as its own decisions'. ${ }^{126}$

This not only allows organisations to differentiate themselves out as self-contained collective action systems, but it also enables them to absorb a considerable degree of societal uncertainty. Once again, this builds on insights of classic organisation studies, and that

\footnotetext{
${ }^{118}$ Luhmann, op. cit. (2013), n. 27, p. 143.

${ }^{119}$ H. Simon, Administrative Behavior: A Study of Decision Making Processes in Administrative Organizations (1957) 34ff.

${ }^{120}$ S. Kühl, Organisations (2013) 98.

${ }^{121}$ Luhmann, id.

122 Peter Benenson, founder of Amnesty International, '40 4 th Anniversary Peter Benenson Quote', AI Index АCT30/009/20001.

123 A. Nassehi, 'Organisations as Decision Machines: Niklas Luhmann's theory of organized social systems' (2005) 53 The Sociological Review 171.

${ }^{124}$ N. Luhmann, 'Organisation', in Autopoietic Organisation Theory: Drawing on Niklas Luhmann's Social Systems Perspective, eds. T. Bakken \& T. Hernes (2003) 32.

${ }^{125}$ M. Knudsen, 'Displacing the Paradox of Decision Making', in Niklas Luhmann and Organisation Studies, eds. D. Seidl \& K. H. Becker (2005) 108.

${ }^{126}$ Luhmann, id., p. 145.
} 
' $[\mathrm{u}]$ ncertainty absorption takes place when inferences are drawn from a body of evidence and the inferences, instead of the evidence itself, are then communicated. ${ }^{127}$ This is typical of modern organisations. Because the decision premise does not need to be re-decided, it does not pass on the uncertainty in such a way that it can become an aggregated condition of the organisation. ${ }^{128}$ Instead, the information is 'condensed at each stage and conclusions are drawn that are no longer checked at the next stage' ${ }^{129}$ Prior to the decision, there is uncertainty because of the open possibilities, and once the decision is made and an option has been chosen, the uncertainty is reduced. ${ }^{130}$

The classic concept of uncertainty absorption has to be developed further, however, with the observation that it is not the decision itself which absorbs the uncertainty, 'but a process that connects decisions. ${ }^{, 131}$ In this way, uncertainty is absorbed at each successive connection between decision premise and decision. Such a graduation of the concept of the decision premise from the structural to the processual level is especially important for explaining how organisations generalise norms in the temporal dimension. As Knudsen points out, it is in the 'time-dimension that decisions fixate contingency and absorb uncertainty', and this absorption of uncertainty even takes the form of the 'stabilization of expectations' ${ }^{132}$ The expectation is carried through time by the recursive decision making of the formal organisation, primed and ready to be projected at a discrepant future, and any uncertainty surrounding it is absorbed from decision to decision.

These insights take on new meaning in relation to the problem of expectations of global public goods which cannot be directly accommodated by society's legal system. The decisionpremise of many social movement organisations is to engage in collective organisation to secure the realisation of such normative expectations, and every decision those formal organisations take after that carries the normative projection through time and absorbs any societal uncertainty surrounding it. In this way, the social movement organisation becomes a channel through which the norm can be carried and a chamber through which social tension

127 J. March \& H. Simon, Organisations (1958) 165.

${ }^{128}$ D. Baecker, 'The Design of Organisation In Society', in Niklas Luhmann and Organisation Studies, op. cit., n. 125, p. 203.

${ }^{129}$ Luhmann, id., p. 147.

130 J. Mingers, 'Observing Organisations: An Evaluation of Luhmann's Organisation Theory', in Autopoietic Organisation Theory, op. cit., n. 124, p. 109.

${ }^{131}$ N. Luhmann, 'The Paradox of Decision Making', in Niklas Luhmann and Organisation Studies, op. cit., n. 125 , p. 96. See also Weick's concept of organisation as process (' $[\mathrm{t}]$ he communication activity is the organisation'), K. Weick, Sensemaking in Organisations (1995) 75.

${ }^{132}$ Knudsen, op. cit., n. 125, p. $115 f$ (emphasis added). See also, T. Drepper, 'Organisation and Society', id., p. 179. 
arising from the problem of such expectations can be dissipated and diffracted. The organisation becomes a self-contained structure into which those norms can expand endlessly without conflict, even without realisation in the general social system, therefore allowing for the absorption of the complexity that ensues in the mismatch of expectations of global public goods and the traditional avenue of the legal system.

However, this by itself is not enough to provide a proper alternative solution to the problem of normative expectations of global public goods. If TSMOs are simple abstract decision machines for norms, a void into which those norms can expand with an infinite regress, they would not provide an adequate functional equivalent to law. Of course, normative expectations are not dependent on enforceability mechanisms which would guarantee the realisation of the expectations - they can resist learning from disappointing experience. For TSMOs, the measured structural autonomy from this obligation can even be said to form the basis of their capacity to represent 'subject matter that none of the function systems, neither politics, nor the economy, neither religion nor education, neither science or law would acknowledge as its own. ${ }^{133}$ However, to foster such expectations, and thereby offer a real alternative to law, TSMOs must at least maintain structural relationships which appear to guarantee the potential enforceability of norms. ${ }^{134}$ To be more precise, this requires building a structural relationship with the existing structural coupling of politics and law at the international level, a task which is made all the more complex by that structural coupling having evolved through both the functional differentiation of law and politics and the segmentary differentiation of the nation-state. Sovereignty is part of the problem for global public goods of course, but so long as civil society can engage the organisations of the international legal and political systems, it can unfold the paradox and present the potential successful realisation of the norm within sovereign nation-states. The international legal system may not yet be able to accommodate many expectations of global public goods-perhaps it never will. But one must be able to expect that if the requisite international legal institutions develop, the norm will be sufficiently stabilised in civil society organisation as to be primed to connect with any emergent legal and political structures.

Rather than requiring methods of 'steering' or 'power', however, the solution to this problem is achieved through the specialised communicative capacity of TSMOs.

\footnotetext{
${ }^{133}$ Luhmann, op. cit. (1993), n. 27, p. 142.

${ }^{134}$ This is also reflected in Luhmann's approach. Even though 'the function of the norm is not aimed at guiding motives', 'normative expectations cannot be practised without a side-glance at their enforceability', Luhmann op. cit. (1985), n. 20, pp. 150-51.
} 
Organisations are the only form of social system which can engage in 'communication on behalf of the collective', and therefore the only social systems that communicate with other systems in their environment. ${ }^{135}$ Interaction systems with face-to-face contact can only communicate within the boundary of present participants, and can only relate to their environment as 'absence'. ${ }^{136}$ Functional systems like law or politics, on the other hand, cannot enter into outward communication as entities. ${ }^{137}$ Therefore, whoever wishes to communicate as a collective with their environment must organise. Organisations not only communicate outward on behalf of the collective, they are also the 'only social systems in modern society that can be addressed as collective actors.' ${ }^{138}$ It is for this reason that organisations are necessary to 'install forms of reflexivity into the function systems', ${ }^{139}$ and why modern society is now 'flooded by representational communication' that is directed at other organisations, 'but never to the function-systems or to the entire society. ${ }^{140}$

This communicative capacity of organisations is very important in the context of normative expectations of global public goods which go unrealised in law. Building upon the way in which the counterfactuality of the norm can remain charged through the recursive decision-making of the social movement organisation, the communicative capacity afforded by the organisational form means that the norm can be simultaneously circulated within its societal environment as a proto-legal communication and continuously projected in this form at organisations of the international legal system. Moreover, this communicative capacity is even more pronounced in social movement organisations which are able to establish a structural coupling with the mass media which ensures that the 'mise-en-scene' of large scale protest movements is presented as a mirror of public opinion and a focal point for their normative expectations. ${ }^{141}$ Indeed, previous research has highlighted the increasing role of transnational civil society organisations in securing 'norm cascades' in the international public sphere, ${ }^{142}$ as the 'engines of the global expansion of human rights', ${ }^{143}$ and as 'socializing' governments into codification of human rights and general welfare norms. ${ }^{144}$

\footnotetext{
${ }^{135}$ Luhmann, op. cit. (2013), n. 27, p. 151; Luhmann, op. cit., n. 24, p. 199-200.

${ }^{136}$ Luhmann, id. (2013), p. 145.

${ }^{137}$ Luhmann, id., p. 151.

${ }^{138}$ Drepper, op. cit., n. 132, p. 182.

${ }^{139}$ Nassehi, op. cit., n. 123, p. 188.

${ }^{140}$ Drepper, op. cit., n. 138.

${ }^{141}$ Luhmann, op. cit. (1993), n. 27, p. 141.

142 Finnemore and Sikkink, op. cit., n. 98.

${ }^{143}$ K. Tsutsui and C. M. Wotipka, 'Global Civil Society and the International Human Rights Movement: Citizen Participation in Human Rights International Nongovernmental Organisations' (2004) 83 Social Forces 587.

${ }^{144}$ E. Hafner-Burton and K. Tsutsui, 'Human Rights in a Globalizing World: The Paradox of Empty Promises' (2005) 110 American Journal of Sociology 1385.
} 
Yet, while the communicative capacity of social movement organisations contributes to such 'norm cascades', all that is required for the generalisation of global public goods norms in the temporal dimension is a communicative capacity to keep norms circulating in their social environment as norms, and thus a presented possibility of a norm cascade in future. The social movement organisation cannot guarantee the norm will be realized-it has not got the power to do so- but it can keep the norm on the world stage, primed for realisation some day in the future, throughout world society and within the necessary secondary differentiation of sovereign nation-states.

Together with its specialisation of recursive decision making on the basis of the norm, this unique communicative capacity of social movement organisation achieves a decisive generalisation of the norm in the temporal dimension.

Using Luhmann's scheme then, the formal organisation of social movements can be said to achieve the congruent generalisation of normative expectations of global public goods in the social, factual and temproal dimensions. Social movement organisation provides an institutional observer who co-expects expectations of global public goods. Such organisation provides a more abstract social meaning to those expectations. Through its decisions, the organisation carries such expectations through time and keeps them primed for projection at any discrepant reality in the future. Through its communicative capacity, the organisation can keep pitching these normative expectations at the international legal and political system, waiting for the day, if it ever comes, where those expectations can be positivized as law. In other words, the emergence of this form of organisation in recent years appears to be a functional equivalent to law in reference to normative expectations of global public goods.

\section{DISCUSSION}

The thesis presented here of the function of TSMOs in relation to normative expectations of global public goods presents an alternative explanation of the proliferation of this form of organisation in globalised society, beyond notions of 'resource mobilisation' ${ }^{145}$ and fragmented 'political process'. ${ }^{146}$ This presents an alternative thesis of such organisational proliferation as functional differentiation in response to the problems which globalisation has exposed in

\footnotetext{
145 See, for example, McCarthy and Zald, op. cit. (1977), n. 30.

${ }^{146}$ See, for example, S. Tarrow, Power in Movement: Social Movements, Collective Action, and Politics (1998).
} 
modern law and governance structures. The article has not claimed this as a universal empirical reality, but it presents this as a real possibility that is worth further specialised empirical research.

Apart from its utility for the design of such method, the theory offers several useful observations. First, it questions the degree to which civil society organisations are really involved in 'political process', and whether some of what is captured and labelled as 'global governance' is not instead a different, apolitical function of stabilising expectations of global public goods. If one ignores the specialised functional relationship between civil society organisation and normative expectations of global public goods, one can easily conflate the public authority which comes with that form of public representation with the different public authority needed to make collectively binding decisions at the global level. This observation fits with existing concerns that 'the study of TSMs tends to magnify their strength and role in the shaping of policies at the global and regional level', and that this 'general tendency is often achieved at the expense of more fine-tuned analysis of the areas which TSMs are likely to influence, their amount of influence, and the way in which it is achieved. ${ }^{147}$ Such observations should not detract anything from global governance studies of course, but rather are offered to increase awareness of an alternative functional specialisation of TSMOs that should only refine global governance studies, and contribute to the development of a more precise focus on governance at the transnational level.

Secondly, in underlining the importance of civil society organisation in the global normative order and in highlighting the contingency of law as a solution in this respect, the theory presented here raises certain questions about the prevailing general exclusion of TSMOs from the international legal system. To date, international law has afforded little recognition of the legitimacy of TSMOs in contributing to the global public order. ${ }^{148}$ Although in recent years more avenues of participation have opened up in this respect, ${ }^{149}$ TSMOs are generally categorised there as 'non-governmental organisations'. As such, they suffer the same general marginalisation of NGOs in formal international legal process and have just as limited standing

\footnotetext{
${ }^{147}$ U. Ben-Eliezer and A. Kemp, 'Transnational Social Movements, Civil Society, and a Secret State: The Idea of a Nuclear-free World through Israel's Vanunu Affair', 7 Social Movement Studies 150-51.

${ }^{148}$ For example, the extent to which civil society organisations were involved in bringing the question about the illegality of nuclear weapons was an issue for the Court in the Nuclear Weapons Opinion, see Sep. Op. Guillame, ICJ rep. 1996, 288.

${ }^{149}$ Most notably, The European Court of Human Rights (see Art. 34 European Convention on Human Rights), The Inter-American Commission of Human Rights (see Art. 44 of the American Convention on Human Rights), and the access to national courts granted through the 1998 Aarhus Convention on Access to Information, Public Participation in Decision-Making and Access to justice in Environmental Matters.
} 
to bring public interest litigation in respect of global public goods. ${ }^{150}$ The perspective gained here, however, abstracts this form of organisation out from the dominating semantic value of the nation-state in law, and steps away from the operative distinction of 'governmental'/"nongovernmental' which effectively renders civil society organisations non-entities in the centre of the legal system. Moreover, it suggests that the fragmentation which international lawyers commonly read as mere 'diversification and expansion of international law', 151 runs much deeper, and presents this instead as a more general fragmentation of normative institutionalisation out beyond the nation-state. From a functional perspective at least, this general fragmentation of normative institutionalisation enjoys as much 'public authority' as it would in a narrower specialisation of this function in the nation-state or the international organisation. With this, it resonates (tentatively) with existing questions as to whether these organisations should not be afforded more legitimacy as a subject of both law and legal research. $^{152}$

We need to be careful here though-descriptions can be functional too. ${ }^{153}$ From the perspective gained here, one can also see how the prevailing description of TSMOs (and the social movements they represent) as 'non-governmental' or 'marginal' may have some functional relevance to the self-description of the global political system. Global problems can no longer be presented as solvable problems within the framework of independent nationstates. Under these conditions, the political system is quickly exhausted and its limits are exposed. With this, there is both less stability and less variability. Less stability because there are important aspects of society outside the state's control. Less variability because the limits of the state in this respect are clear and appear terminal. However, the evolution of social movement organisation presents an alternative in this respect. Even if social movement organisations cannot govern global issues (cannot 'steer', do not have 'power'), they can communicate an 'external standpoint ${ }^{\text {' }}$ " which in turn stimulates political communication. This would be further evidence of the way in which 'modern society has destabilized its

\footnotetext{
${ }^{150}$ P-M. Dupuy, 'Conclusion: return on the legal status of NGOs and on the methodological problems which arise for legal scholarship', in NGOs in International Law: Efficiency in Flexibility?, eds. P. M. Dupuy and L. Vierucci (2008) 214. Moreover, international law is said to have remained 'virtually isolated' from the more basic social movements, B. Rajagopal, International Law from Below: Development, Social Movements and Third World Resistance (2003) 246.

${ }^{151}$ Report of the Study Group of the International Law Commission on the Fragmentation of International Law, U.N. Doc. A/CN.4/L.628. 13 April 2006, para. 1.

${ }^{152}$ See, for example, Lindblom, op. cit., n. 85.

${ }^{153}$ Luhmann, op. cit., n. 24, p. 62. For a more basic and popular thesis, see Y. N. Harari, Homo Deus: A Brief History of Tomorrow (2015).

${ }^{154}$ Luhmann, op. cit. (1993), n. 27, p. 140.
} 
structures and enriched its potential for saying 'no', and that it is increasingly unimportant 'whether the 'no' is articulated from positions of legal strength or in the context of social movements'. 155

The proliferation of TSMOs in this sense represents an internal differentiation of the global political system. On the semantic level at least, it decentres the state as the 'universal point of reference for politics', ${ }^{156}$ and activates political communication on the global scale. Sovereignty will always interrupt the paradox of this description, of course, just as it frustrates the realisation of global public goods, but in doing so it provides the other side of a distinction, a governance which can be opposed. In this way, politics does not run aground with globalisation and can overcome some of the most stalling problems of sovereignty in world society.

If 'non-governmental organisations' have achieved such a semantic value in the political system, then their contribution to meaningful communication in world society may well depend upon their continued marginalisation from central political structures. This would only stunt the further inclusion of TSMOs into an international legal system which remains structurally coupled with the global political system of segmentarily differentiated sovereign states. The co-evolution of the political system and social movement organisation under these conditions could then involve an entrenched dislocation of the latter from power as a generically symbolised form of communication. This raises the possibility that the semantic value of such organisations to the global political system could undermine the operational value of such organisations in the universal realisation of global public goods.

There is perhaps another possibility, nonetheless, that these semantic structures are capable themselves of providing some basis for an expanded political system and its structural coupling with law at the global level. The question, ultimately, is whether the semantic value of the social movement organisation in its liminal 'opposition' will acquire a constitutional significance. Social movements are increasingly recognised for their role in an important 'constitutionalism from below'. ${ }^{157}$ Gunther Teubner (who has also employed Luhmann's systems theory, albeit from a very different perspective), has, for example, recently presented the development of the social movement as a 'sectorial constitution' to which law can externalise its foundational paradox to gain legitimacy, and which in turn allows the social

\footnotetext{
${ }^{155}$ Luhmann, op. cit. n. 24, p. 404.

${ }^{156}$ Luhmann, op. cit. (2000), n. 19, p. 215.

157 G. Anderson, 'Societal Constitutionalism, Social Movements, and Constitutionalism from Below' (2013) 20 Indiana Journal of Global Legal Studies 881.
} 
movement to acquire legitimacy as part of a fragmented transnational public order which is free from state constitutions. ${ }^{158}$ The thesis presented here, however, suggests that constitutional studies can only be developed in this direction through a methodological shift away from distinctions such as 'spontaneous/organised-professional', ${ }^{159}$ or 'left-wing/right-wing'160 which obscure the importance of social movement organisation. More radical still, it will require a fundamental shift away from focusing on the problem of political unity at the transnational level and the solution of specialised and pluralistic constitutionalism, and a switch instead to a focus on the problem of stabilising highly generalised normative expectations of global public goods and its alternative solutions.

The necessary shift applies also to the prevailing governance and power focus in legal conceptions of global public goods, but it relates on an even more general level to the so-called 'post-modern' development of social sciences. Conceptions of common concern and a global public are commonly avoided in research as they appear utopian and unrealistic in relation to the obvious pluralism of world society. Attention has generally shifted instead to what can be achieved through a network of specialised and differentiated public spheres. However, the paradigm has only obscured insights into how highly generalised expectations of global public goods are important to the evolution of world society (a co-dependency of specialisation and generalisation). This article has focused on the functional differentiation of civil society organisations in relation to global public goods as an example of the complex structural arrangements which emerge under these conditions. In doing so, it stresses the importance of a proper engagement of the problems of highly generalised expectations of global public goods as a possible step towards a more ecological development of society's legal system.

\footnotetext{
${ }^{158}$ G. Teubner, 'Exogenous Self-Binding: how social subsystems externalise their foundational paradox in the process of constitutionalism', in Sociology of Constitutions: A Paradoxical Perspective, eds. A. Febbrajo and G. Corsi (2016) 39.

159 Teubner, op. cit. n. 23, pp. 88-92.

${ }^{160}$ Kjaer does recognise formal organisations of normative orders as 'the object of constitutions', and at a point even identifies NGOs as constituting 'normative orders in their own right'. But after a false dichotomy is drawn in which 'left-Luhmannians' focus on social movements and 'systematically disregard the organisational aspect', this is never really explored, see Kjaer, op. cit. n. 23, 139-519. The normative significance of TSMOs under this perspective appears limited to their internal order, while their function in respect of the global public goods they represent is limited to the transfer of meaning components and mutual adaptation (i.e., purely cognitive).
} 